\title{
REFORMASI HUKUM TATA NEGARA INDONESIA: PERUBAHAN KEKUASAAN EKSEKUTIF, LEGISLATIF DAN YUDIKATIF BERDASARKAN AMANDEMEN UNDANG-UNDANG DASAR 1945
}

\author{
Budi Darmono
}

\section{Abstrak}

This article does scrutiny on the latest progress at post amendment of Constitution of Republic Indonesia. Commonly, implication of the amendment does reflecting significant change through executive, legislative and judicative powers. Here elaborated many significant changes such as the more constricted power of People Consultative Assembly (MPR), President and wider power of House of People Representative (DPR). MPR has no more power to constitute the president, because the president currently elected by direct elections and have no responsibility to MPR but still have power to impeach the president by Mahkamah Konstitusi recommendations. The another new is on the forming of Dewan Perwakilan Daerah, then reflected tricameral of Indonesian Parliament structure (MPR, DPR, DPD) In judicative power has settled the Court of Constitution (Mahkamah Konstitusi) that hold judicial review power against constitution violence by law regulation. More issues on judicative power also can be seen on many special tribunal settled such as human rights, corruption, after has been initiated in 1999 by commercial court.

Kata kunci:hukum tata negara, reformasi hukum, perubahan kekuasaan, amandemen UUD 1945

Kejatuhan pemerintahan Soeharto membawa akibat yang luas terhadap kehidupan bangsa Indonesia dan sistem kenegaraan Indonesia. Kehidupan bangsa menjadi lebih demokratis. Demokratisasi juga menjangkau kehidupan politik dengan diubahnya seperangkat undang-undang yang menyangkut kegiatan politik sehingga kegiatan politik menjadi sangat bebas dan terbuka. Jumlah partai politik pun meningkat drastis. Perubahan lebih lanjut terjadi pada sistem ketatanegaraan dengan diamandemennya Undang-Undang Dasar 1945. Masa ini dikenal dengan masa reformasi.

Selama 54 tahun sejak diberlakukannya pada tahun 1945, UndangUndang Dasar 1945 belum pernah diubah. Undang-undang dasar ini sebenarnya mengamanatkan kepada Majelis Permusyawaratan Rakyat 
(MPR) untuk membentuk undang-undang dasar yang baru dalam waktu 6 bulan sejak diberlakukannya undang-undang dasar ini karena UndangUndang Dasar 1945 dibuat dalam keadaan darurat. Sebagai akibat dari keadaan darurat ini, UUD 1945 tidak dibuat secara terperinci. Pembuatannya pun dilakukan oleh panitia yang tidak dipilih melalui pemilihan umum.

Namun MPR itu sendiri gagal dibentuk karena situasi darurat perang sebab setelah menyerahnya Jepang kepada Sekutu, Belanda mencoba merebut kembali wilayah jajahannya tetapi harus menghadapi perlawanan rakyat Indonesia. Selama keadaan darurat perang dan masa-masa sesudah penyerahan kedaulatan dari Belanda kepada Indonesia, Undang-Undang Dasar 1945 diganti dengan Undang-Undang Dasar Republik Indonesia Serikat dan Undang-Undang Dasar 1950. Namun kedua undang-undang dasar ini pun bukanlah hasil keputusan Majelis Permusyawaratan Rakyat.

MPR barulah terbentuk melalui pemilihan umum 1955. Namun MPR ini gagal membentuk undang-undang dasar karena dalam proses pengambilan keputusannya selalu menemui jalan buntu (deadlock). ${ }^{1}$ Pada tahun 1959 Presiden Soekarno melalui Dekrit Presiden 1959 menyatakan UUD 1945 berlaku kembali. Dimasa Orde Baru, MPR hasil pemilu 1971 tidak membuat undang undang dasar baru. MPR bahkan mengukuhkan UUD 1945. Selama masa pemerintahan Soeharto, UUD 1945 tidak mengalami perubahan sama sekali.

Setelah Soeharto berhenti menjadi presiden, terjadi perubahan sistem politik yang diikuti pemilihan umum pada tahun 1999. MPR hasil pemilihan umum inilah yang mulai melakukan amandemen UUD 1945 pada tahun 1999. Amandemen kedua dilakukan pada tahun 2000 yang diikuti amandemen ketiga pada tahun 2001 dan amandemen keempat pada tahun 2002. Setelah amendemen keempat, UUD 1945 tidak lagi singkat tetapi terperinci. Meskipun masih terdiri 37 pasal namun pasal-pasal itu berkembang, misalnya pasal 28 menjadi pasal 28A, 28B, 28C dan seterusnya. Jumlah pasal sekarang menjadi 73 pasal. Amandemen ini mengakibatkan perubahan dalam sistem pemerintahan, kekuasaan presiden, kekuasaan parlemen dan lembaga peradilan.

\section{Sistem Pemerintahan}

Nampaknya Indonesia masih mencari sistem pemerintahan yang permanen. Pada saat didirikannya di tahun 1945, Indonesia adalah negara kesatuan. Akan tetapi kemudian berubah menjadi negara federasi, sebagai

' Ismail Sunny, The Review of Constitutionality of Decisions in Indonesia, In: University of Indonesia Law Journal, Vol. 1, No.1, October 1999, (Faculty of Law, University of Indonesia Publishing House), hal. 14 
akibat dari perundingan panjang dengan Belanda. Susunan negara kemudian kembali menjadi negara kesatuan. Bentuk pemerintahan pun berubah. Pada awalnya presidensiil, namun kemudian berubah menjadi parlementer setelah pemilihan umum 1955. Bentuk pemerintahan kembali menjadi presidensiil setelah dekrit presiden tahun 1959. Bentuk presidensiil murni inipun ada yang meragukan karena dalam sistem ini terkandung ciri-ciri parlementer, seperti misalnya adanya jabatan perdana menteri yang memiliki kekuasaan yang cukup besar.

\section{Pra Amandemen}

Seperti telah disebutkan diatas, Indonesia dianggap menganut bentuk pemerintahan yang presidensiil. Alasannya ialah bahwa presiden mengangkat dan memberhentikan menteri serta memimpin eksekutif. Presiden pun memegang kekuasaan untuk menjalankan undang-undang dengan membuat peraturan pemerintah dan keputusan presiden.

Akan tetapi Sri Sumantri meragukan sistem ini merupakan bentuk pemerintahan presidensiil murni. Alasannya ialah bahwa dalam sistem ini terdapat karakteristik parlementer seperti yang terlihat dalam kekuasaan MPR yang mengangkat dan memberhentikan Presiden. Jadi sistem ini merupakan campuran dari presidensiil dan parlementer. ${ }^{2}$ Kombinasi karakteristik parlementer dan presidensiil juga terlihat dalam pertanggungjawaban tugas Presiden kepada MPR sebagai ciri parlementer dan pertanggungjawaban tugas menteri kepada Presiden sebagai ciri presidensiil. ${ }^{3}$

Oleh karena itu Azhary berpendapat sebaiknya sistem ini dinamai sistem MPR. Ada lima alasan yang mendukung argumentasinya. Pertama, MPR memegang kekuasaan negara tertinggi. Kedua, kegiatan kenegaraan berpusat di MPR. Ketiga, DPR yang merupakan badan legislatif menjadi bagian dari MPR yang menjalankan kedaulatan rakyat. Keempat, Presiden diangkat dan diberhentikan oleh MPR. Kelima, MPR memegang kekuasaan untuk mengamandemen dan membuat undang-undang dasar serta

${ }^{2}$ Sri Sumantri, "Sistem-Sistem Pemerintahan Negara-Negara ASEAN", (Bandung: Transito, 1976), hal. 52, 54, dan 56.

3 Mohamad Kusnardi, dan Bintan Saragih, "Susunan Pembagian Kekuasaan Menurut UUD 45", (Jakarta: Gramedia, 1978), hal. 69. 
Garis-Garis Besar Haluan Negara yang merupakan pedoman bagi pemerintah. ${ }^{4}$

MPR juga memegang kedaulatan rakyat. Supremasi MPR mencakup dua aspek, yakni kekuasaan yang diberikan oleh konstitusi dan tiadanya lembaga negara yang menyamai kedudukannya. ${ }^{5}$ Kekuasaan MPR ini kemudian didelegasikan kepada: Presiden sebagai lembaga eksekutif; Dewan Perwakilan Rakyat sebagai lembaga legislatif; Mahkamah Agung sebagai lembaga yudikatif; Badan Pemeriksa Keuangan sebagai lembaga inspektif; dan Dewan Pertimbangan Agung sebagai lembaga konsultatif.

Walaupun MPR adalah lembaga tertinggi negara dan pemegang kedaulatan rakyat, MPR tidak mengelola negara setiap hari. Selama periode 5 tahunan masa kerjanya, tugas MPR hanyalah mengangkat Presiden, membuat Garis-Garis Besar Haluan Negara, dan meminta pertanggungjawaban Presiden. Tugas harian pengawasan terhadap eksekutif dilakukan oleh DPR. Diakhir masa jabatan Presiden, MPR menilai pertanggungjawaban Presiden dan menentukan apakah menerima atau menolaknya.

DPR adalah bagian dari MPR. Tugasnya adalah mengawasi pemerintah yang dipimpin oleh Presiden. Disamping itu, tugas DPR adalah bersama dengan Presiden membuat undang-undang. Kedudukan DPR setara dengan Presiden. DPR tidak bisa memberhentikan Presiden. Demikian pula President tidak dapat membubarkan DPR.

Dibidang keuangan, Presiden diawasi oleh DPR dan BPK. Anggaran Pendapatan dan Belanja Negara (APBN) tahunan harus disetujui oleh DPR. Pendapatan dan belanja negara diaudit oleh BPK. Untuk alasan ini kedudukan BPK tidak dibawah Presiden.

\section{Pasca Amandemen}

Pasca amandemen, sebagian kekuasaan MPR dilucuti. Kini MPR tidak lagi memegang kedaulatan rakyat. MPR tidak lagi mengangkat Presiden karena Presiden dipilih langsung oleh rakyat. MPR bukan lagi lembaga tertinggi negara. Presiden tidak

${ }^{4}$ Azhary, SH, "Negara Hukum Indonesia: Suatu Analisis Yuridis Normatif tentang Unsur-Unsurnya", (Ringkasan Disertasi), (Program Pasca Sarjana Universitas Indonesia, 1993), hal 14-16

${ }^{5}$ Ismail Sunny, Op. Cit., hal. 16. 
lagi bertanggung jawab kepada MPR. Walaupun MPR masih memegang kekuasaan untuk memberhentikan Presiden dalam masa jabatannya, proses pemberhentian Presiden harus melalui suatu prosedur panjang dan ketat yang harus melibatkan DPR dan Mahkamah Konstitusi. Tanpa keterlibatan DPR dan Mahkamah Konstitusi, MPR tidak dapat memberhentikan Presiden. GarisGaris Besar Haluan Negara ditiadakan. Tugas MPR sekarang hanyalah membuat dan mengamandemen undang-undang dasar. Tugas inipun tidak perlu dikerjakan apabila undang-undang dasar yang ada dinilai sudah memadai. Perlucutan sebagian kekuasaan MPR dengan sendirinya merubah sistem. Kini sistem ini tidak dapat lagi dinamai sistem MPR. Karakteristik parlementer juga tidak lagi ditemukan. Oleh karena itu sistem pemerintahan lebih tepat disebut presidensiil murni.

Lembaga negara baru terbentuk, yakni Dewan Perwakilan Daerah (DPD) dan Mahkamah Konstitusi (MK). DPD mewakili kepentingan propinsi. Tidak seperti DPR, anggota DPD dipilih langsung diwilayah pemilihannya masing-masing. Anggota DPD tidak mewakili partai politik. Mereka mewakili kepentingan dan aspirasi daerah dan rakyat diwilayahnya masing-masing. Jumlah wakil tiap propinsi di DPD sama meskipun jumlah penduduk di tiap propinsi berbeda. Kewenangan DPD lebih kecil dari kewenangan DPR dalam proses pembuatan undang-undang dan pengawasan pemerintah. DPD hanya memiliki kewenangan dalam lima bidang, yaitu: otonomi daerah; hubungan antara pemerintah pusat, pemerintah propinsi, dan pemerintah kabupaten/kota; pembentukan, pemekaran, dan penggabungan propinsi, kabupaten dan kota; pengelolaan sumber daya alam dan ekonomi; dan perimbangan keuangan pusat, propinsi, dan kabupaten/kota. DPD terlibat dan aktif dalam proses pembentukan undang-undang yang menyangkut kelima bidang tersebut dan mengawasi penegakannya. Anggota DPD adalah anggota MPR.

Mahkamah Konstitusi memiliki lima tugas pokok. Pertama, MK memeriksa kasus peninjauan suatu undang-undang apakah suatu undang-undang bertentangan dengan Undang-Undang Dasar. Kedua, MK mengadili dan memutus sengketa antar lembaga negara. Ketiga, MK mengadili dan memutus sengketa partai politik. Keempat, MK mengadili dan memutus sengketa hasil pemilihan umum. Kelima, MK memberikan pendapat hukum dalam proses pemberhentian Presiden dan Wakil Presiden. Dengan demikian fungsi MK adalah sebagai penjaga Undang- 
Undang Dasar dan hakim bagi sengketa antar lembaga negara dan politik.

\section{Kekuasaan Presiden}

\section{Pra Amandemen}

Dalam sejarah Indonesia, dua presiden yang sangat berpengaruh dan berkuasa adalah presiden pertama, Soekarno, dan presiden kedua, Soeharto. Mereka memerintah negeri ini dalam kurun waktu yang lama: 21 tahun dan 32 tahun. Sumber pengaruh Soekarno adalah kharismanya. Soeharto dilain pihak membangun sistem politik dan hukum untuk mendukung pengaruh dan kekuasaannya.

\section{Pemerintahan Soekarno}

Sejak awal berdirinya republik, sistem pemerintahan seringkali berubah. Meskipun secara umum dikatakan bentuk pemerintahan presidensiil, Presiden, selama pemerintahan Soekarno, acapkali berbagi kekuasaan dengan Perdana Menteri. Bentuk pemerintahan ini juga diselingi oleh bentuk parlementer setelah pemilihan umun 1955. Bentuk pemerintahan parlementer berakhir pada tahun 1959 pada saat Presiden Soekarno menerbitkan Dekrit Presiden 1959 yang membubarkan parlemen dengan alasan ketidak mampuan parlemen membuat keputusan menyebabkan terjadinya krisis politik. Sebagai gantinya, Presiden mengangkat anggota parlemen. Dengan pengangkatan anggota parlemen oleh Presiden, parlemen tidak lagi independen, melainkan tunduk dibawah pengaruh Presiden. Dibidang eksekutif, Presiden sekaligus Perdana Menteri. Presiden juga mengangkat Wakil Perdana Menteri. Dibidang yudikatif, Presiden mengangkat Ketua Mahkamah Agung. Presiden juga mengangkat Ketua Badan Pemeriksa Keuangan. Dengan demikian kekuasaan memusat ditangan Presiden. Tidak ada lagi prinsip checks and balances dalam penyelenggaraan negara, padahal prinsip ini merupakan syarat dalam pemerintahan negara yang demokratis. Selain tidak demokratis, pembubaran parlemen merupakan pelanggaran Undang-Undang Dasar. Keadaan ini berlangsung sampai dengan berakhirnya kekuasaan Presiden Soekarno. 


\section{Pemerintahan Soeharto}

Presiden Soeharto memiliki gaya berbeda dari pendahulunya. Ia secara formal patuh pada Undang-Undang Dasar 1945 dan menjaganya dalam arti mencegah setiap upaya untuk mengamandemennya. Dilain pihak ia menerapkan UndangUndang Dasar 1945 dengan cara membangun sistem politik dan hukum yang mendukung kekuasaannya melalui pembuatan undang-undang dan peraturan pelaksanaannya. Dengan kata lain, berbeda dengan Soekarno, Soeharto mengakumulasikan kekuasaan melalui hukum formal. Ia memanfaatkan kelemahan Undang-Undang Dasar 1945 yang singkat dan tidak terperinci.

Pada awalnya ia membangun Golongan Karya sebagai kendaraan politik. Dengan dukungan birokrasi dan militer ia memenangkan pemilihan umum. Kemenangan politik ini ia manfaatkan untuk mendominasi MPR dan DPR. Dengan dukungan MPR dan DPR ia dengan mudah membuat seperangkat undang-undang politik yang memungkinkan seorang Presiden mengangkat sebagian anggota MPR dan DPR yang pada gilirannya akan mendukungnya. Kombinasi antara anggota MPR dan DPR yang diangkat oleh Presiden dan anggota MPR dan DPR dari Golongan Karya memungkinkannya mempertahankan kekuasaan karena MPR akan memilihnya sebagai Presiden dan DPR akan mendukungnya dalam pembuatan undang-undang yang substansinya menguntungkannya secara politis.

Selain itu, dibidang yudikatif, undang-undang juga memberikan keistimewaan kepada Presiden, melalui Menteri Kehakiman, untuk mengangkat, memberhentikan, mempromosikan, menentukan gaji dan memutasi hakim. Kewenangan ini membuat Presiden, sebagai atasan Menteri Kehakiman, memiliki pengaruh sangat kuat terhadap hakim. Hal ini membuat hakim tidak lagi mandiri dihadapan Presiden. Pengaruh Presiden atas yudikatif diperbesar dengan kewenangan Presiden mengangkat Ketua Mahkamah Agung. Badan Pemeriksa Keuangan sebagai auditor lembaga negara juga tidak terlepas dari pengaruh Presiden karena Ketua BPK diangkat oleh Presiden.

Dengan demikian, dalam masa pemerintahan Soekarno dan Soeharto, kekuasaan politik dihimpun ketangan Presiden. Pemisahan kekuasaan direduksi menjadi pembagian kekuasaan yang artinya Presiden dapat mempengaruhi lembaga tinggi negara lainnya. Pemusatan kekuasaan dipermudah oleh ketentuan 
Undang-Undang Dasar 1945. Sebelum amandemen, UUD 1945 menentukan bahwa kedaulatan rakyat dijalankan oleh MPR. Kemudian MPR membagikan kekuasaannya kepada lembagalembaga tinggi negara (Presiden, DPR, MA, BPK). Dengan mendominasi MPR, Presiden sekaligus menjalankan kedaulatan rakyat.

\section{Pasca Amandemen}

Pasca amandemen UUD 1945, sebagian wewenang Presiden dilucuti. Presiden tidak lagi berwenang mengangkat anggota MPR dan DPR. Kini seluruh anggota MPR dan DPR harus melalui pemilihan umum. Presiden tidak berwenang lagi mengangkat Ketua Mahkamah Agung dan Badan Pemeriksa Keuangan. Menteri Kehakiman, bawahan Presiden, tidak lagi mengurusi pengangkatan, promosi, pemberhentian maupun mutasi hakim. Dibidang yudikatif, wewenang Presiden hanya dalam hal pemberian grasi, amnesti dan abolisi. Itupun harus melalui rekomendasi MA. Dengan demikian kini Majelis Permusyawaratan Rakyat, Dewan Perwakilan Rakyat, Mahkamah Agung dan Badan Pemeriksa Keuangan menjadi lebih mandiri.

\section{Parlemen}

\section{Pra Amandemen}

Parlemen dibagi dalam dua badan, yakni MPR dan DPR. MPR terdiri dari seluruh anggota DPR ditambah dengan Utusan Golongan dan Utusan Daerah. Seluruh anggota Utusan Golongan dan Utusan Daerah diangkat oleh Presiden. Sebagian anggota DPR, misalnya dari Fraksi ABRI diangkat oleh Presiden.

Tugas DPR adalah mengawasi pemerintah dan bersama dengan Presiden membuat undang-undang. Dalam hal pengawasan pemerintah dimasa pemerintahan Soekarno, DPR sulit menjalankan tugasnya karena anggota DPR diangkat oleh Presiden. Dimasa pemerintahan Soeharto, DPR pun tidak leluasa melakukan tugasnya karena sebagian besar anggota DPR adalah dari Golongan Karya, dimana Soeharto adalah figur yang paling berkuasa, dan dari Fraksi ABRI, dimana seluruh anggotanya diangkat oleh Presiden. Dalam hal pembuatan undang-undang, DPR dalam prakteknya menjadi pihak yang pasif. Prakarsa pembuatan undang-undang berasal dari pemerintah. Alasannya 
adalah mereka lebih mampu dalam hal penyediaan tenaga ahli dan dana.

Tugas MPR adalah mengangkat Presiden dan membuat Garis Garis Besar Haluan Negara. Dimasa pemerintahan Soekarno, MPR tidak pernah mengangkat Presiden dan membuat Garis Garis Besar Haluan Negara dengan alasan: pertama, masa kerja Presiden tidak dibatasi, bahkan MPR mengangkat Soekarno menjadi presiden seumur hidup; kedua, Presiden tidak membutuhkan Garis Garis Besar Haluan Negara. Walaupun kedua hal ini melanggar UUD 1945, MPR tidak berani bertindak karena anggota MPR diangkat oleh Presiden. Dimasa pemerintahan Soeharto, MPR melaksanakan tugasnya mengangkat Presiden setiap lima tahun sekali. MPR juga membuat Garis Garis Besar Haluan Negara (GBHN). Dalam hal pengangkatan Presiden, MPR sangat terpengaruh oleh Presiden, karena sebagian anggota MPR diangkat oleh Presiden dan sebagian lainnya dari Golongan Karya. Kedua kelompok ini merupakan kelompok mayoritas dalam MPR. Dalam hal pembuatan GBHN, draf GBHN disiapkan oleh pemerintah dan dalam prakteknya MPR tidak merubah draf ini secara signifikan.

\section{Pasca Amandemen}

Parlemen kini dibagi dalam tiga badan: MPR, DPR, dan DPD. MPR bukanlah gabungan DPR dan DPD sebagai lembaga, melainkan gabungan anggota DPR dan anggota DPD sebagai perorangan. Jadi MPR tidak terdiri dari DPR dan DPD melainkan terdiri dari anggota DPR dan DPD. Dengan demikian parlemen Indonesia bukan bikameral melainkan trikameral. Diantara ketiga badan ini, yang paling berpengaruh adalah DPR karena kewenangan DPR paling luas. Semua undang-undang harus melalui DPR. Selain itu DPR mengawasi pemerintah dalam semua bidang. Pengangkatan pejabat ekesekutif tertentu pun harus disetujui DPR, misalnya Panglima TNI, duta besar. Kalau sebelum amandemen prakarsa pembuatan undang-undang selalu datang dari eksekutif, kini DPR lebih banyak mengambil inisiatif dalam proses pembuatan undang-undang. 


\section{Sistem Peradilan}

\section{Pra Amandemen}

Undang-Undang Dasar 1945 menyatakan kekuasaan kehakiman bebas dari pengaruh siapapun. Kebebasan hakim dalam memutus perkara juga dijamin oleh undang-undang. Akan tetapi pengangkatan, pemberhentian, promosi, mutasi, dan penentuan gaji hakim menjadi kewenangan Departemen Kehakiman. Disamping itu pengangkatan Ketua Mahkamah Agung ditentukan oleh Presiden. Dengan demikian, meskipun secara yuridis hakim bebas namun secara administratif hakim dipengaruhi oleh eksekutif. Oleh karena itu dalam kasus-kasus yang menyangkut kepentingan eksekutif, seperti misalnya kasus tanah yang menyangkut pejabat pemerintah atau lembaga pemerintah, hakim cenderung memenangkan pihak pemerintah. ${ }^{6}$

\section{Kekuasaan Peninjauan Yuridis atau Judicial Review}

Undang-Undang Dasar 1945 memberikan kekuasaan kepada Mahkamah Agung untuk melakukan peninjauan yuridis. Yang dimaksud dengan peninjauan yuridis ialah pemeriksaan apakah produk hukum dibawah undang-undang (peraturan pemerintah, keputusan presiden, peraturan menteri, peraturan daerah dan sebagainya) bertentangan dengan undang-undang. Apabila MA berpendapat bahwa suatu produk hukum bertentangan dengan undang-undang, maka MA dapat menyatakan produk hukum tersebut harus dibatalkan. Namun selama pemerintahan Soekarno dan Soeharto, MA belum pernah membatalkan produk hukum dibawah undang-undang yang merupakan produk hukum dari eksekutif.

\section{Pasca Amandemen}

Kekuasaan Presiden dan Menteri Kehakiman yang berkaitan dengan hakim dilucuti. Kini pengangkatan, pemberhentian, promosi, mutasi, dan gaji hakim ditentukan oleh Mahkamah

'Budi Darmono. 'Adat' and Land Law in a Plural System: A Study of Forestry Regulations and Indonesian 'Legal Development'. Disertasi. Faculty of Law, the University of Melbourne. 2004), hal 130, 141, 160, 172. 
Agung. Ketua Mahkamah Agung pun sekarang dipilih oleh para hakim agung. Dengan demikian hakim kini lebih mandiri.

\section{Kekuasaan Peninjauan Yuridis}

Kekuasaan peninjauan yuridis dipegang oleh Mahkamah Agung dan Mahkamah Konstitusi. MA berwenang meninjau produk hukum dibawah undang-undang untuk menentukan apakah produk hukum tersebut bertentangan dengan undangundang. MK berwenang meninjau undang-undang untuk menentukan apakah undang-undang tersebut bertentangan dengan undang-undang dasar. Dengan kata lain, MA merupakan penjaga undang-undang, sedangkan MK adalah penjaga undang-undang dasar.

\section{Peradilan Khusus}

Peradilan khusus untuk mengadili perkara yang berkaitan dengan pelanggaran hak asasi manusia dapat diselenggarakan. Namun masih terdapat perbedaan penafsiran undang-undang terhadap prosedur penyelenggaraan peradilan khusus hak asasi manusia antara DPR dengan Kejaksaan Agung. Kejaksaan Agung berpendapat bahwa peradilan khusus dapat dibentuk jika DPR menemukan pelanggaran hak asasi manusia. DPR dilain pihak berpendapat bahwa pembentukan peradilan khusus tidak tergantung dari penemuan DPR. Menurut DPR, Kejaksaan Agung adalah lembaga yang berkewajiban untuk menemukan pelanggaran hak asasi manusia dan menindaklanjuti penemuan tersebut dengan membentuk peradilan khusus hak asasi manusia.

Selain peradilan khusus hak asasi manusia, kini peradilan khusus tindak pidana korupsi dapat diselenggarakan. Namun MK berpendapat bahwa peradilan khusus tindak pidana korupsi harus diatur dengan undang-undang. 


\section{Daftar Pustaka}

Azhary. 1993, Negara Hukum Indonesia: Suatu Analisis Yuridis Normatif tentang Unsur-Unsurnya (Ringkasan Disertasi), Program Pasca Sarjana Universitas Indonesia.

Darmono, Budi. 'Adat' and Land Law in a Plural System: A Study of Forestry Regulations and Indonesian 'Legal Development', Disertasi, Faculty of Law, the University of Melbourne, 2004.

Kusnardi, Mohamad, dan Bintan Saragih, Susunan Pembagian Kekuasaan Menurut UUD 45, Jakarta: Gramedia, 1978.

Sumantri, Sri. Sistem-Sistem Pemerintahan Negara-Negara ASEAN, Bandung: Transito, 1976.

Suny, Ismail. The Review of Constitutionality of Decisions in Indonesia, In: University of Indonesia Law Journal, Vol.1, No.1, October 1999, Faculty of Law, University of Indonesia Publishing House. 